\title{
Multiculturalism of Kyai in Pesantren Sunni Darussalam, Yogyakarta
}

\author{
Sabarudin* \\ Tarbiyah and Teacher Training Faculty \\ UIN Sunan Kalijaga \\ Yogyakarta \\ sabarudin@uin-suka.ac.id
}

\begin{abstract}
Multiculturalism is an issue that is always actual and interesting. It is seen as actual because it involves the diversity that will always exist in the reality of human life. And it is also considered interesting because some conflicts that occurred in social life are the result of an effort to disclaim diversity. The pesantren world, which since its inception in the archipelago is an institution that is very close to the issue of multiculturalism, later also had become a lively discussion due to the emergence of a diversity of pesantren with diverse religious understandings, as a result of the massive transnational Islamic Movement entering the entire archipelago. This presented study is qualitative field study of study of Suni Darussalam pesantren in Sleman Yogyakarta. It aims to provided enriching information on multiculturalism discourse of pesantren, also to showed how the views of Islamic boarding school clerics in the modernization era, disruptive era, which is full of globalization of various values and ideologies. The results of the study showed that: first, Kyai in pesantren Suni Darussalam understands multiculturalism as an attitude to acknowledge and accept differences, but not necessarily dissolve in the views of others, but individuals should have strong beliefs with their own views. Second, the actualization of the Kyai's multiculturalism views were reflected in his attitude and behavior such as having openminded responses to differences, showing the diversity of views of the students and the community, and showing them about the views they hold. Actualization of the kyai's multiculturalism attitude was also shown from his attitude which prefers to prioritize the moral approach in preaching he does, rather than highlighting differences (ikhtilaf) to realize social harmony.
\end{abstract}

Keywords-Islamic religious scholars, multiculturalism, moral approach, social harmony

\section{INTRODUCTION}

Kyai is the central figure and the most influential figure in the boarding school environment. This assumption is supported by the fact that the establishment of pesantren cannot be separated from the initiation and struggle of the kyai. Likewise, in terms of its growth and development, the figure of the kyai also became the main pillar of the dynamics of the pesantren. The ideology adopted and believed by the kyai also helped determine the direction of the scientific and religious traditions that developed in the pesantren.

The socio-cultural setting of the community also cannot be separated from the history of pesantren and its development. Pesantren aslo cannot be separated from the socio-cultural setting of the community. That factor may be the underlying basis of the assumption that pesantren are educational institutions which have a "natures" style. With this style, then discussing the issue of multiculturalism in the context of pesantren is actually not something strange [1]. Moreover, the accommodative tendency towards pluralism has been shown by pesantren since its early development as in the Wali Songo era, where pesantren were able to integrate various cultural elements: Islam, Javanese, Hinduism and Buddhism, through the uniqueness of the Islamic acculturation process with diverse local cultures.

Along with the increasingly diverse development of religious "ideology" [2] in the country as well as the strengthening of the flow of modernization [3] and globalization [4] in the disruptive era [5], the face of pesantren does not becomes a monolithic face. In this modern era there are many types of pesantren typologies.[6] On the one hand, there are many pesantren that idealize traditional principles and implement the traditional system the traditional system, but on the other hand, many pesantren are also accommodate the modernization and implement the modern system. However, conversely there are also pesantren which is very skeptical to modernization, they tend to be militant and exclusive.

Interaction of pesantren with the world of formal academic institution (universities) encourages the occurrence of scientific and religious discourse which in turn displays certain "Islamic" patterns [7]. In this regard, pesantren are required to transform [8] and change their traditions to give positive and negative responses to the insistence of the campus world. This interaction can occur through many channels, including: Islamic boarding school clerics who are graduated from university and at the same time working as academician in university [9], Some religious teachers and education personnel are university alumni, some students at pesantren are also university students/college students. Moreover, nowadays many pesantren start using IT-based learning models [10], and pesantren start to develop education program which has the same level with university system [11].

One of the problems that arose in the intersection of pesantren with the world of formal academic institution (university) and the impact of globalization is the issue of multiculturalism. The issue of multiculturalism is getting stronger along with the proliferation of religious movements that tend to be exclusive, including in Islam. Islamic boarding schools as a basis for Islamic defense and studies, more or less reap the impact, especially when pesantren appear based on research results, are considered to be exclusive and radical, which are generally characterized by their tendency to interpret texts in a way that ignores the 
context, tends to sharia enforcement (Sharia minded), and anti-pluralism [12].

Sunni Darussalam Islamic Boarding School, which is the object of this research study, has strong role in terms of considering the intersection between modern formal academic and pesantren culture. In this pesantren, the clerics, the leader, and the religious teachers have formal educational background from university, they also take part in academic (university) world, and also some of the students here (santri) also study at the university. As a central figure, the kyai's views on multicultural issues are interesting to be analyzed because they can be a point of view of the extent to which pesantren and campus interrelations have rolled out the discourse of transformative thinking.

The problems answered in this article are the views of kyai in pesantren regarding the problem of multiculturalism and the effort that kyai in pesantren has implemented in terms of actualizing these views into the pesantren and education process.

Studies related to pesantren and multiculturalism or similar have indeed been carried out by Abdullah Aly [13], M. Syaefudin Zuhri [14], Sabarudin [15], Zakiyuddin Baidhawy [16], Mahmud Arif [17], and Budi Pranoto [18]. This presented study has certainly several differences with previous studies. In addition, this study has proposed certain pesantren as the formal object compare to previous studies and explored several problems related to multiculturalism in pesantren. This article examined multiculturalism from the perspective and experience of the kyai in pesantren. Data in this study was gathered using in depth interview particularly both structured and unstructured interviews [19] with informants (kyai) [20], it was also supplemented with observations and documentation studies, with data analyses using theory triangulation method [21].

\section{RESULT AND DISCUSSION}

\section{A. A Glance of Sunni Darussalam Boarding Schools}

Sunni Darussalam Islamic boarding school was founded by Nyai Hj. Umroh Mahfudhoh in the village of Nomporejo RT 04 Wedomartani Ngemplak Sleman. The initiation of the establishment of this Islamic boarding school cannot be separated from the role of her husband, Prof. Dr. KH. Mohammad Tholhah Mansur, SH., Who in 1984 had aspired to founding. But because in 1985 he was very ill and died in 1986, then the plan was delayed. It was only in 1988 Nyai Hj. Umroh Mahfudhoh decided to settle in Tempelsari Sleman and started a business building a cottage with a waqf land capital of $2000 \mathrm{~m} 2$ [22].

Nyai Hj. Umroh Mahfudhoh, is the descendants of the ulema (daughter of the KH Wahib Wahab and $\mathrm{Hj}$ Siti Channah) from Gresik, East Java, she is also the founder of the Nahdlatul Ulama Female Student Association (IPPNU) and activists in politics. She was once a member of the Indonesian Parliament, both when she joined with PPP and PKB the two popular Islamic party in Indonesia [23].

At first the emphasis on activities in the pesantren was only routine recitation for the community. In subsequent developments the activities were increasingly complex, because later Diniyah Madrasah educational activities was also emerged. Even today the Sunni Darussalam boarding school has several educational activities, such as: Madrasah Diniyah, TK Darussalam Plus, and Madrasah Aliyah. The number of students also increased and varied levels, both among students, S1 and S2 students [24]. After Nyai $\mathrm{Hj}$. Umrah Mahfudhoh died, the care of the Islamic boarding school turned to his son-in-law's son, Dr. KH. Ahmad Fatah, M.Ag., one of the lecturers at the Faculty of Adab and Cultural Sciences of UIN Sunan Kalijaga, husband of $\mathrm{Hj}$. Nisrin Nikmah, the fourth child of KH. M. Tolchah Mansur and Nyai Hj. Umrah Mahfudhoh [25].

Learning activities carried out after sunset and dawn, with curriculum / learning based on kitab kuning / yellow book (the traditional set of the Islamic texts used by the educational curriculum of the Islamic seminary in Indonesia, especially within the madrasahs and pesantrens which includes studies in the fields of: Arabic/Grammar Arabic; Usul Fiqh and Fiqh; Morals/Sufism; Islam history; Qur'anic Interpretation and Hadith. Learning activities at the pesantren are carried out at night after the evening prayers and in the morning after the morning prayer, using the bandongan system. In addition, there are also weekly Bahtsul Masail activities, with the theme of the study being adjusted to the actual daily issues in the scope of fiqh, although it is still within the framework of the Salafiyah anNahdhiyah school of thought [26].

\section{B. Kyai's View and Actualization on Multiculturalism}

Kyai Ahmad Fatah (AF), leader (traditional Muslim clerics) of Sunni Darussalam pesantren, interpreted multiculturalism as an appreciative awareness of the existence of diversity and differences in society. He said, "There is an opinion that we follow, but we still appreciate the arguments of other opinions. As much as possible we do not judge other opinions wrong. When the public we face is heterogeneous, we emphasize more on the delivery of moral material" [27].

There are two things that should be underlined from the statement above, namely: first, the Kyai avoids excessive truth claims, and second, the Kyai appreciates the paradigm / moral perspective. Excessive truth claims tend to negate the possibility of being right in other opinions and "force" others to follow their opinions. Recognizing the reality of a pluralistic society, in presenting the religious material of Kyai AF as much as possible explaining the diversity of existing opinions accompanied by their respective arguments. The audience is given leeway to choose one opinion without having to blame the other's opinion. Nevertheless, Kyai AF still tried to explain which opinion he personally chose. With this attitude, Kyai AF teaches tolerance in the determination of opinion.

Furthermore, the fiqh perspective appreciated by the Kyai $\mathrm{AF}$ indicates that serious obstacles to multiculturalism often emerge from the strong perspective of fiqh in the religious level of society. This assumes that fiqh is very directly related to a variety of practical daily activities of a person. Jurisprudence is a kind of practical guide for someone to behave and act "from waking up to going to sleep again". In fact, it is common for jurisprudence to be positioned as a parameter to judge a person's diversity, whether he can be categorized as pious or not. If that is the case, then figh has functioned as a paradigm (perspective), so it determines what is believed and in turn determines what is done. [28] In short, paradigm or perspective is not only cognitive, but also affective. Paradigms / perspectives not only affect the way someone thinks about reality, but also affect the way they approach and act on reality. The plurality of our society is a reality, when figh has become a paradigm, it greatly 
influences our judgment, attitude, and actions towards the reality of society.

Making figh as a paradigm (perspective), by Jalaluddin Rachmat, is considered not favorable, because it will be trapped in a formalistic attitude, and tends to ignore the more fundamental dimensions in Islam, namely morals. This is the reason that underlies the need to change the paradigm of fiqh, from formalistic fiqh to ethical fiqh, by integrating the wisdom of the law (the moral dimension) into the law [29]. In this context, one form of ethical figh is the social figh paradigm which starts from the view that overcoming complex social problems is seen as the main concern of Islamic law.

In harmony with Islamic morality, that being assertive, according to Kyai AF, is different from being harsh with other groups (non-Muslims); not being vigilant in solving problems; need for dialogue in the delivery of material in learning / recitation; critical attitude towards radical-militant religious movements such as ISIS and the liberal Islamic movement [30]. These are the two sides of active tolerance, namely being tolerant for various differences of opinion, being able to synergize despite of differences, and having the determination to hold opinions according to what is believed. With these two sides, active tolerance that underlies multiculturalism is not the same as a permissive attitude (all permissible) towards all forms of deviation under the freedom of speech/opinion context.

In a broader spectrum, the socio-religious attitude exemplified by Kyai AF actually represents the basic attitude of the majority of Muslims in the country [31], despite being a silent majority, they are able to live side by side peacefully and cooperatively with followers of other religions on the basis of mutual understanding, mutual respect, and trust each other. Such socio-religious attitude is what equips the readiness of Muslims to navigate the global relation with all its opportunities and challenges [32]. Even though the inclusive religious attitude had a solid basis, the realization of the effort on the ground did not take place smoothly. The ideology of "returning to the Qur'an and Sunnah" embraced by some contemporary religious movements which validates a number of violent campaigns, facing the West, non-Muslims as enemies of Islam, is the most difficult challenge for inclusive religious attitudes [33].

Another challenge that is still often encountered is the strength of figh which introduces a less positive (discriminatory) perspective towards other religious communities [34]. Such conditions are caused by the writing period of jurisprudence which is not conducive, the internal situation of Muslims that is not solid, and also the presence of religious symbols that implicitly encourage a harsh attitude towards other religions [35]. Jamal al-Banna termed this kind of jurisprudence with the dimension of degradation (conservative) jurisprudence that was not in line with the paradigm of revival of the people [36]. Conservative jurisprudence tends to close itself to liberalism, pluralism and secularism.

Borrowing the term al-Banna, Kyai AF tried to move away from the perspective of conservative fiqh in addressing diversity even though he continued to appreciate the normative dictum of traditional figh. Traditional books combined with contemporary books, actual issues, and the use of campus academic references influence the perspective of the Kyai AF so that he tends to display moderate and inclusive attitudes [37]. Borrowing Amin Abdullah's language, Kyai AF seeks to provide an explanation of the teaching text with a deep contextual study which related to current reality. The moderate and inclusive attitude shown may also be an implication of the appreciation of the values of Sufism such as humility, patience, tolerance, and tolerance that have internalized themselves [38].

Kyai AF strongly emphasized the understanding of moderatism (tawassuthiyah) and tolerance (tasamuh) by holding on to normative dictum of traditional books which used to be the content of learning in various pesantren. As a traditional Islamic boarding school cleric who is also an academic (lecturer), Kyai AF appear to be open to actual demands even though he continues to prioritize cautious policy in articulating thoughts and carrying out his leadership role.

This cannot be separated from the religious "ideology" and the socio-cultural context of the rural community (urban edge) encountered. Such methods and approaches, by Ahmad Suaedy, are referred to as the Islamic Posttraditionalism approach, namely an Islamic approach that prioritizes the reinterpretation of aspects of Islamic teachings based on classical Islamic scientific traditions and traditions that live in contemporary society in order to respond to changes that occur in modern society.[39] The perspective and attitude and behavior of Kyai AF reflected in his wisdom in seeing diversity of views, his willingness to respect differences, his ability to contextualize Islamic teachings, as well as emphasizing assertiveness rather than violence in addressing the differences that mentioned above, thus his wisdom shows that he is a multiculturalist figure. Because, as explained by Musa Asy'ary (Choirul Mahfud) [40], that multiculturalism is wisdom in seeing the diversity of cultures in society.

\section{CONCLUSION}

Based on the discussion above, it can be concluded: first, that the Kyai of Suni Darussalam pesantren is already very familiar with the issue of multiculturalism. His familiarity is reflected in his perspective in viewing multiculturalism which he means as an attitude to be ready to recognize and accept differences, although it does not have to dissolve in the views of others, but must still have strong beliefs with the views he believes. Second, his perspective on multiculturalism, then actualized in his attitude and behavior that is always open to differences, shows the diversity of views of the students and the community, and shows them which views they hold. The actualization of Kyai's multiculturalism attitude is also shown from his attitude which prefers to prioritize the moral approach in preaching he does, rather than highlighting differences (ikhtilaf) to realize social harmony.

\section{REFERENCES}

[1] Abdullah Aly, "Studi Deskriptif Tentang Nilai-Nilai Multikultural dalam Pendidikan di Pondok Pesantren Modern Islam Assalaam" dalam Jurnal Ilmiah Pesantren, Volume I, Nomer 1, Januari-Juni 2015, hlm. 9-22

[2] Roni Dwi Hartanto, "Mengkaji Relasi Agama dan Ideologi”, dalam jurnal Dinika: Akademik Journal of Islamic Studies, Volume 1, Number 1, Januari-April 2016, hlm. 81-90. Ali Muhtarom, "Ideologi Transnasionalisme dan Jaringan Lembaga Pendidikan”, (Disertasi PPs UIN Sunan Kalijaga Yogyakarta, 2019).

[3] M. Yusuf Chudlori, "Interaksi Pesantren dengan Nilai-nilai Modernitas" Makalah Simposium Nasional Pendidikan Agama dan Keagamaan, tanggal 4-7 Oktober 2011 di Hotel Shapir Yogyakarta, 
Puslitbang Pendidikan Agama dan Keagamaan Balitbang dan Diklat Kemenag RI, hlm. 102-118

[4] Sri Andri Astuti, "Pesantren dan Globalisasi", dalam Jurnal Tarbawiyah, Vol.11 No.1 Edisi Januari-Juli 2014, hlm.16-33

[5] Samsudin, "Tantangan Lembaga Pendidikan Pesantren di Era Disrupsi”, makalah Conference on Islamic Studies (CoIS) 2019, hlm. 221.

[6] Sabarudin, Pesantren dan Nilai-nilai Demokrasi, Yogyakarta: Fakultas IlmuTarbiyah dan Keguruan UIN Sunan Kalijaga Yogyakarta, 2018, hlm. 60-63.

[7] Abdul Muqsith Ghozali, "Membangun Tradisi Baru Keilmuan Pesantren" makalah Simposium Nasional Pendidikan Agama dan Keagamaan....., hlm.119-134.

[8] Mujamil Qomar, "Transformasi Pendidikan Pesantren", makalah Simposium Nasional Pendidikan Agama dan Keagamaan...., hlm. 72-101.

[9] Akhmad Minhaji, "Transformasi Paradigma Ilmu-ilmu Keislaman PTAI di Indonesia" makalah Simposium Nasional Pendidikan Agama dan Keagamaan..., hlm. 222-292

[10] Agus Zainal Arifin, Model Pengembangan Pembelajaran Kitab Kuning di Pesantren Berbasis IT" makalah Simposium Nasional Pendidikan Agama dan Keagamaan..., hlm. 135-150.

[11] Bashori "Modernisasi Lembaga Pendidikan Pesantren Perspektif Azyumardi Azra" dalam Nadwa Jurnal Pendidikan Islam Vol. 11, Nomor 2 Tahun 2017, hlm. 269

[12] Munawar Rahmat, "Corak Berpikir Agama Mahasiswa", dalam Jurnal Pendidikan Agama Islam-at-Ta'lim, Vol. 10, No. 1, 2012, hlm.13-37.

[13] Abdullah Aly, "Studi Deskriptif Tentang Nilai-Nilai Multikultural dalam Pendidikan di Pondok Pesantren Modern Islam Assalaam" dalam Jurnal Jurnal Ilmiah Pesantren, Vol.I, No. 1, Januari-Juni 2015, hlm. 9-22

[14] [M. Syaifuddien Zuhriy, "Budaya Pesantren dan Pendidikan Karakter Pada Pondok Pesantren Salaf", dalam Jurnal Walisongo: Jurnal Penelitian Sosial Keagamaan, hlm. 287-308

[15] Sabarudin, "Multikulturalisme Kyai Pesantren: Studi Pandangan Kyai Tentang Persoalan Multikultural dan Aktualisasinya dalam Pendidikan Pesantren Islamic Center Bin Baz di Yogyakarta", dalam Jurnal Forum Tarbiyah STAIN Pekalongan Vol.13 No.2, Edisi Desember 2015.

[16] Zakiyuddin Baidhawy, "The Problem of Multiculturalism: Radicalism Mainstreaming Through Religious Preaching in Surakarta" (Journal of Indonesian Islam, IAIN Surabaya, Vol.04, Number 02, December 2010)

[17] Mahmud Arif, "Pengembangan Pendidikan Agama Islam Berwawasan Multikultural: Telaah terhadap Silabus Matakuliah KePAI-an Fakultas Tarbiyah UIN Sunan Kalijaga" (Hasil Penelitian Lemlit UIN Suka, 2009

[18] Budy Pranoto, "Paradigma Kyai Pesantren Salafiyah dalam Mempertahankan Visi-Misi di Era Globalisasi (Studi Kasus Pesantren al-Falah Ploso Kediri)" (Tesis Pascasarjana MPI UIN Malang, 2007)
[19] Andrea Fontana dan James H. Frey, "Wawancara: Seni Ilmu Pengetahuan" dalam Norman K. Denzim dan Yvonna S. Lincoln, Handbook of Qualitatif Ressearch, terj. Dariyatno, dkk., Yogyakarta: Pustaka Pelajar, 2009, hlm.501-518. Nana Syaodih Sukmadinata, Metode Penelitian Pendidikan, Bandung: Remaja Rosda Karya, 2011, hlm.112.

[20] Lexy J. Moleong, Metodologi Penelitian Kualitatif, Bandung: Remaja Rosda Karya, 2004, hlm. 190-191

[21] Mohammad Ali, Memahami Riset Perilaku dan Sosial, Bandung: Pustaka Cendekia Utama, 2011, hlm.259-260.

[22] Sepenggal Cerita di Sunni Darussalam Sleman dalam http://karepee.blogspot.com/2012/11/sepenggal-cerita-di-sunnidarussalam.html, diunduh Maret 2020.

[23] Ibid.

[24] Wawancara dengan Dr. KH. Ahmad Fatah, M.Ag., Pengasuh PP. Sunni Darussalam Tempelsari Maguwoharjo, Depok, Sleman, DI.Yogyakarta.

[25] Sepenggal Cerita di Sunni Darussalam Sleman dalam http://karepee.blogspot.com..., diunduh Nopember 2020.

[26] Wawancara dengan Dr. KH. Ahmad Fatah, M.Ag., Pengasuh PP. Sunni Darussalam.

[27] Ibid.

[28] Jalaluddin Rakhmat, Dahulukan Akhlak di atas Fikih (Bandung: Mizan, 2007), hlm.37.

[29] Sahal Mahfudh, Nuansa Fiqih Sosial (Yogyakarta: LKiS, cet. IV, 2004), hal. xlix.

[30] Wawancara dengan Dr. KH. Ahmad Fatah, M.Ag., Pengasuh PP. Sunni Darussalam, Tempelsari Maguwoharjo, Depok, Sleman, DI.Yogyakarta.

[31] Nurcholish Madjid, Islam, Doktrin dan Peradaban (Jakarta: Paramadina, cet. IV, 2000), hal. 179 .

[32] Ibid., hal. 177-196.

[33] Zuhairi Misrawi, Al-Qur'an Kitab Toleransi: Tafsir Tematik Islam Rahmatan Lil 'Alamin (Jakarta: Pustaka Oasis, 2010), hal. 15.

[34] Abd. Moqsith Ghazali, Argumen Pluralisme Agama: Membangun Toleransi Berbasis Al-Qur'an (Jakarta: Katakita, 2009), hal. 9-10.

[35] Mun'im A. Sirry (ed.), Fiqih Lintas Agama: Membangun Masyarakat Inklusif-Pluralis (Jakarta: Paramadina, 2004), hal. 143.

[36] Jamal al-Banna, Manifesto Fiqih Baru I: Memahami Diskursus AlQur'an, terj. Hasibullah Satrawi dan Zuhairi Misrawi (Jakarta: Erlangga, 2008), hal. v-vi.

[37] Wawancara dengan Dr. KH. Ahmad Fatah, M.Ag., Pengasuh PP. Sunni Darussalam.

[38] Sabarudin, Pesantren dan Nilai-nilai Demokrasi,...hlm.318. Lihat, M. Amin Abdullah, Pendidikan Agama Era MultikulturalMultireligius, Yogyakarta: PSAP Muhammadiyah, 2005, hlm.77-81

[39] Ahmad Suaedy, Gus Dur, Islam Nusantara, dan Kewarganegaraan Bineka, Jakarta: PT. Gramedia Pustaka Utama, 2018, hlm.392.

[40] Choirul Mahfud, Pendidikan Multikultural, Yogyakarta: Pustaka Pelajar, 2008, hlm. 103 